\title{
ホブ切りにおける全面コーティングエ具の摩耗挙動に 及ぼす水溶性切削油剤の影響*
}

\author{
松岡寛 憲*1, 小野 肇*2, 津田吉広*1

\section{Influence of Water-Soluble Cutting Fluids on Wear Behavior of} \\ Fully Coated Tool in Hobbing
}

\author{
Hironori MATSUOKA*3, Hajime ONO and Yoshihiro TSUDA \\ ${ }^{* 3}$ Department of Mechanical and Energy Systems Engineering, Oita University, \\ 700 Dannoharu, Oita-shi, Oita, 870-1192 Japan
}

\begin{abstract}
In this paper, the wear behavior of $(\mathrm{Al}, \mathrm{Ti}) \mathrm{N}$ fully coated tools was investigated when using two kinds of water soluble cutting fluids for hobbing, which were compared with city water and dry cutting. Experiments were carried out using a fly tool. The results helped clarify the following points: (1) A water-soluble cutting fluid containing synthetic lubricating additive is effective for the flank wear, which is smaller than that obtained when using the city water only. The flank wear obtained with the dry cutting is smaller than that obtained with the water-soluble cutting fluids tested. (2) The fluid containing synthetic lubricating additive retards the occurrence of crater wear on the coated rake face in comparison with the dry cutting, and its crater wear ia also small. (3) It was suggested that the crater wear mechanism of fully coated tool is that first, the delamination and/or the seizure of the coating film caused by thermal fatigue occurs, and after appearing the substrate, the crater wear increased by the abrasive action with the cutting chips.
\end{abstract}

Key Words : Cutting, Gear, Water-Soluble Cutting Fluid, Hobbing, Fly Tool, Fully Cated Tool, Flank Wear, Crater Wear, Finished Surface Roughness

\section{1. 緒言}

近年, 切削油剤について, 切削性能の向上より，む しろ使用中の作業環境や使用後の廃液処理による環境 污染などの環境問題に対する関心が高まってきてい る.これらの問題に対して, 旋削, フライス加工およ びドリル加工などでは水溶性切削油剤がかなり普及し てきており，水溶性切削油剤(原液)の生産量は全切削 油剤生産量の約 40\%を占めるようになってきてい る(1).しかしながら, ホブ切りにおいては, 工具摩耗 および仕上げ面粗さなどの点から不水溶性切削油剤の 使用が主流であり，鋼製歯車の歯切りでの水溶性切削 油剤の使用比率は $10 \%$ 程度であると報告されてい る(2). ホブ切りに水溶性切削油剤の使用が可能になれ ば, ミストや臭気による作業環境の悪化や引火の危険 性などの問題が解決されるだけではなく，優れた冷却 作用によって，熱膨張による精度低下も少なくなる。

通常, 摩耗したホブはすくい面を再研削し, コーテ ィング膜は取り除かれて使用する場合が多い.しかし

\footnotetext{
* 原稿受付 2005 年 4 月 18 日.

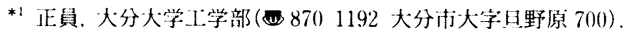

*2工シロ化学丁業(株)品所保部部( 4101305 静岡県駿東郡 小町湯船 11572 2)。

E mail : hmatsuo (a cc.oita u.ac.jp
}

ながら, 最近では, 再コーティング技術の改善やコー ティングコストの低下, 納期の短縮などにより, 再コ 一ティングを施した全面コーティングホブでのホブ切 りが可能となってきている．再コーティングを施し， 全面コーティングホブの使用が可能になれば，すくい 面にコーティング膜がない場合に比べて，切削速度を 上げることができ，また工具寿命も延びるため,さら なる生産性の向上が期待できる.

著者らは, ホブ切りを舞いツール切削にシミュレー トして, すくい面にコーティング膜がない工具での水 溶性切削油剤の効果について調べた結果, 従来から使 用されているホブ切り用不水溶性切削油よりも，エマ ルション形の水溶性切削油剂は切削性能が良く(3)，ま たソリューブル形のエステル系合成潤滑添加剂を含む 水溶性切削油剤も有効であることを報告している(4). しかしながら，全面コーティング工具を使用した場合 の水溶性切削油剂の切削性能については未検討であ り,すくい面にコーティング膜がない工具と比較して， 工具摩耗など, 特にコーティング膜が存在する場合の クレータ摩耗の挙動が異なることが予想される.

本研究では, 合成潤滑添加剂を含有するエマルショ ン形の水溶性切削油剤の効果について, 全面コーティ ング工具の逃げ面摩耗とクレータ摩耗抽よび仕上げ面 
粗さの点から検討を行った。

\section{2. 実験方法および実験条件}

実験方法としては，ホブ切りをフライス盤での舞い ツール切削に置換えて実験を行った。ホブ切りと舞い ツール切削との対応性については, 不水溶性切削油を 使用した場合であるが，両者はほぼ合うことを確認し ており(5)，舞いツール切削での実験結果は実機でのホ ブ切りにも十分適応できるものと思われる。

実験で対象とした歯車はモジュール3, 歯数 42 枚の 平歯車で, ホブは 3 条, 右巻ホブである。フライス盤 の実験条件を表 1 に示す。ホブ材質は高速度鋼工具 SKH 55 相当で，(Al，Ti) N コーティングを，アーク イオンプレーティング法により施し, 全面コーティン グの状態で実験を行った。コーティング膜の厚さは約 $5 \mu \mathrm{m}$ である。被削材はクロムモリブデン鋼 SCM 415 (HB 143) で，その寸法は長さ $500 \times$ 幅 $100 \times$ 厚さ $100 \mathrm{~mm}$ である。切削速度は，すくい面にコーテ

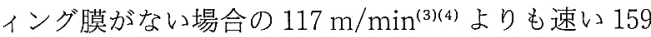
$\mathrm{m} / \mathrm{min}$ である。

図１に工具刃先の損傷を示す。外周切れ刃の中央摩 耗と外周角部摩耗，刃先丸み部と側面切れ刃の境界に 生じる角摩耗およびすくい面のクレータ摩耗を測定し た. 本実験では，フライス盤で溝 $50 \mathrm{~m}$ を切削したが, これは実験の対象とした歯車 161 個分に相当する。ま た,クレータ摩耗は，図 2 に示すように舞いツールの

Table 1 The same conditions as in the case of hobbing by fly tool cutting on milling machine

\begin{tabular}{|c|c|c|c|c|}
\hline \multicolumn{2}{|c|}{ Hobbing } & \multicolumn{3}{|c|}{ Fly tool cutting on milling machine } \\
\hline \multicolumn{2}{|c|}{ 3-thread hob } & Feed of table & \multicolumn{2}{|c|}{$0.99 \mathrm{~mm} / \mathrm{rev}$} \\
\hline Feed of hob & $3.0 \mathrm{~mm} / \mathrm{rev}$ & Depth of cut & \multicolumn{2}{|c|}{$3.25 \mathrm{~mm}$} \\
\hline \multirow{2}{*}{$\begin{array}{l}\text { Length of } \\
\text { maximum chip }\end{array}$} & \multirow{2}{*}{$23.57 \mathrm{~mm}$} & \multicolumn{3}{|c|}{ For cutting corresponding to the gear } \\
\hline & & \multirow{2}{*}{\multicolumn{2}{|c|}{$\begin{array}{l}\text { Total number of revolutions } \\
\text { (The sum of the approach } \\
\text { distance and face width) }\end{array}$}} & \\
\hline \multirow{2}{*}{$\begin{array}{l}\text { Thickness of } \\
\text { maximum chip }\end{array}$} & \multirow{2}{*}{$0.27 \mathrm{~mm}$} & & & \\
\hline & & \multicolumn{2}{|c|}{ Length of groove to be cut } & $0.31 \mathrm{~m}$ \\
\hline
\end{tabular}

Note: The turning radius of the tip of fly tool is $85 \mathrm{~mm}$.
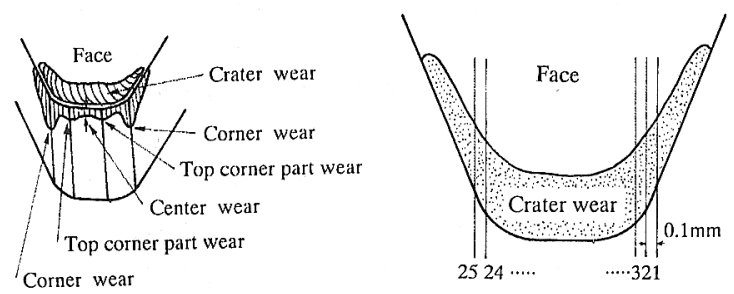

Fig. 1 Wear at cutting Fig. 2 Measurement posiedge tion of crater wear
軸に平行に $0.1 \mathrm{~mm}$ 間隔で 25 点測定した．仕上げ面 粗さは切削溝の底を測定した。使用したフライス盤は 日立精機製 $2 \mathrm{MF}$ 形(万能形)である.

実験に使用した市販のエマルション形の水溶性切削 油剤(以下，油剤と略称する)の性状を表 2 に示す。油 剤 $\mathrm{A}$ は合成潤滑添加剤を含む油剤, 油剤 $\mathrm{B}$ は油剤 $\mathrm{A}$ の合成潤滑添加剤の約半分を鉱油で置換えた油剤であ る。なお，本報で用いる合成潤滑添加剤とは，一般に 合成潤滑油の基油などに多用されている有機酸エステ ルやポリアルキレングリコールなどに限定する。ま た，水道水およびドライ切削で実験を行い，油剂との 比較を行った。油剤は水道水で 30 倍に希釈して，す くい面側より $2.41 / \mathrm{min} の$ 割合で十分に注いだ。

\section{3. 実験結果および考察}

$3 \cdot 1$ 逃げ面摩耗 図 3 に, 满 $50 \mathrm{~m}$ 切削後の逃げ 面摩耗幅の比較を示す。油剤 $\mathrm{A}$ および油剤 $\mathrm{B}$ を比較 した場合, 両者とも最大逃げ面摩耗幅 (中央, 外周角部 および角摩耗のうちの最大) は $0.2 \mathrm{~mm}$ 程度を示すが, 全体的に見た場合，油剤 Aのほうがわずかに摩耗は 小さい，油㶡中の成分が有効に働いているかを調べる ため，水道水だけで実験を行った。その結果，図 $3 に$

Table 2 Properties of water-soluble cutting fluids tested

\begin{tabular}{|c|c|c|c|}
\hline \multicolumn{2}{|l|}{ Item } & Fluid A & Fluid B \\
\hline \multirow{2}{*}{ Appearance } & Original & Yellow liquid & $\begin{array}{l}\text { Light yellow } \\
\text { liquid }\end{array}$ \\
\hline & $\times 30$ & $\begin{array}{l}\text { White } \\
\text { emulsion }\end{array}$ & $\begin{array}{l}\text { White } \\
\text { emulsion }\end{array}$ \\
\hline $\begin{array}{l}\text { Specific gravity } \\
\left(15^{\circ} \mathrm{C}, \mathrm{g} / \mathrm{cm}^{3}\right)\end{array}$ & Original & 0.945 & 0.946 \\
\hline $\mathrm{pH}$ & $\times 30$ & 9.4 & 9.8 \\
\hline $\begin{array}{l}\text { Surface tension } \\
(\mathrm{mN} / \mathrm{m})\end{array}$ & $\times 30$ & 32 & 32 \\
\hline $\begin{array}{l}\text { Synthetic lubricating } \\
\text { additive }\end{array}$ & Original & (2) & 0 \\
\hline Mineral oil & Original & - & (C) \\
\hline Surfuric EP additive & Original & - & - \\
\hline Surface active agent & Original & $\Delta$ & $\triangle$ \\
\hline
\end{tabular}

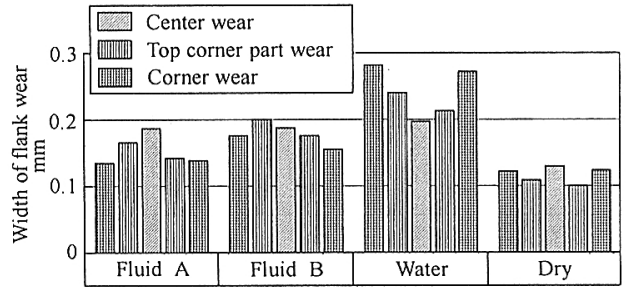

Fig. 3 Comparison of the width of flank wear (cutting length of groove of $50 \mathrm{~m}$ ) 
示すように, 水道水の場合, 両油剤に比べて逃げ面摩 耗は大きくなった. 油剤よりも水道水のほうが熱伝導 率が高く, 冷却性能の点では優れていると思われるが, それよりもむしろ油剤中の合成潤滑添加剤や鉱油の潤 滑性能が有効に働いているものと推察される。さら に, ドライ切削の場合, 逃げ面摩耗は油剤を使用する よりも小さい.これには熱心力が関係しているものと 思われる.すなわち, ホブ切り(舞いツール切削) は断 続切削であり, 油剂を使用した場合, 工具の切れ刃は 切削時には切削熱により高温に加熱され，切れ終わっ た瞬間に, 油剤により強制冷却されるため, 刃先に加 熱と冷却に伴う膨張と収縮の繰返しによる熱応力が発 生する.しかしながら, ドライ切削の場合, 空転時に は空気による冷却であり, 油剤に比べて空気の熱伝導 率は小さいため, 熱応力も小さくなり, 摩耗が減少し たものと思われる.

本実験では，切削温度を測定していないが，油剤 $\mathrm{A}$ およびドライ切削の場合の切削温度の違いについて, 排出された切りくずの色より推定を行った. 図 4 は, 油剤 $\mathrm{A}$ 抢よびドライ切削の場合, 切削始めと清 $50 \mathrm{~m}$ 切削後の切りくずを示す. 油剤 A の場合, 切削始め よりも溝 $50 \mathrm{~m}$ 切削後の切りくずのほうがうす黄色に 変色していることから, 切削温度は高いと推定され る.これに対しドライ切削の場合, 切削始めより紫色 の切りくずを排出しており, 油剤を用いるよりも切削 温度は高く, 清 $50 \mathrm{~m}$ 切削後には, 泎青紫色に変わっ ていることから,さらに切削温度は高くなっている(6) と思われる。これより, 油剤を用いるほうがドライ切 削よりも, 切削温度が低く, 冷却されていることがわ かる.

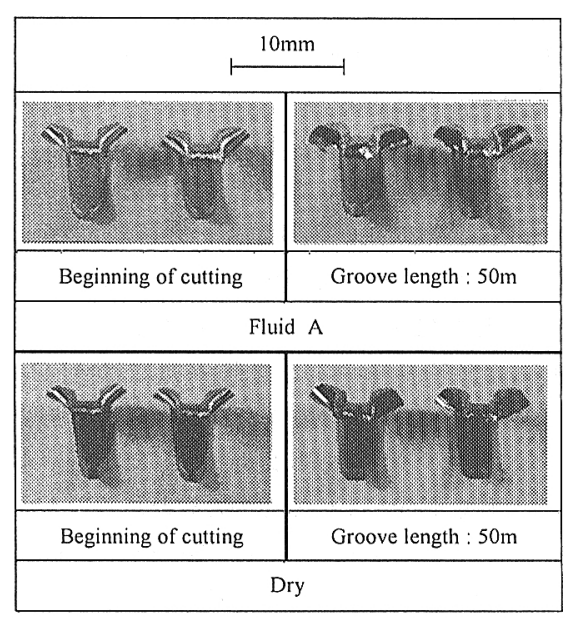

Fig. 4 Comparison of the cutting chips
図 5 は, 比較として, 切削速度 $159 \mathrm{~m} / \mathrm{min}$ における すくい面にコーティング膜がない場合の油剂 $\mathrm{A}$ (切削 溝 $20 \mathrm{~m}$ ) およびドライ切削 (切削清 $4 \mathrm{~m}$ ) での逃げ面摩 耗を示したものである. 図 3 に示すすくい面にコーテ イング膜がある場合とは逆に，油剤 A を用いた場合 に, ドライ切削よりも 5 倍の瑇長さを切削しているに もかかわらず，逃げ面摩耗は小さい。また，この場合 のドライ切削では, 切削瑇長さ $4 \mathrm{~m}$ で最大逃げ面摩耗 幅は $0.4 \mathrm{~mm}$ にも達しており，すくい面にコーティン グ膜がある場合のドライ切削に比べて, 工具寿命は極 端に短くなっている。ドライ切削においては，すくい 面のコーティング膜の有無が逃げ面摩耗に大きく影響 していることがわかる。

さらに, 図 3 に示す全面コーティング工具の場合に 比べて, すくい面にコーティング膜がない場合に, 油 戍では角摩耗, ドライ切削では中央, 外周角部摩耗が 大きく，局部的に大きな摩耗が発生することが特徵的 である、以上より，すくい面にコーティング膜がない 場合には，油剤を用いるほうが有効である。

図6に, 全面コーティング工具の最大逃げ面摩耗の 経過朋線を示す。油剤 $\mathrm{A}$ および油剂 $\mathrm{B}$ の場合, 切削 溝 $10 \mathrm{~m}$ 末では初期摩耗で, 摩耗は $0.1 \mathrm{~mm}$ 程度まで 急激に増加し, 溝 $50 \mathrm{~m}$ 切削後の摩耗愊の約 $50 \%$ がこ の㸺長さまでに発生している。それ以降は $0.2 \mathrm{~mm}$ まで緩やかに摩耗は増加している。両者とも, ほぼ同

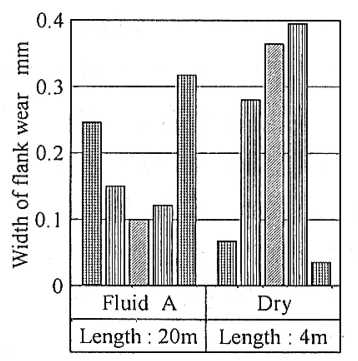

Fig. 5 Comparison of the width of flank wear (without coating on the rake face)

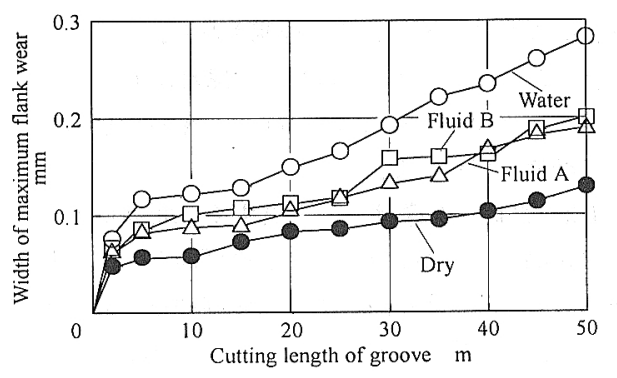

Fig. 6 Progress curves of the maximum flank wear 


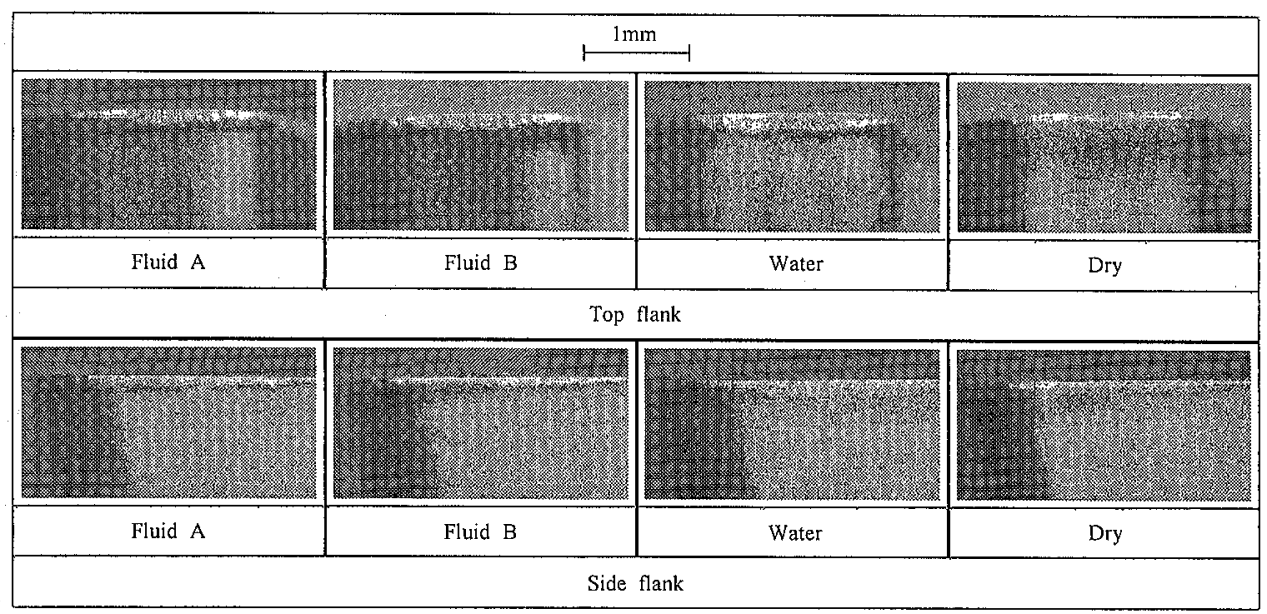

Fig. 7 Conditions of the top flank wear and the side flank wear (cutting length of groove of $50 \mathrm{~m}$ )

じ割合で摩耗注增加しているが, 摩耗は油剂 A のほ うがわずかに小さい. 水道水の場合, 切削濩 $5 \mathrm{~m}$ まで 摩耗は急激に増加し; その後は, 直線的に增加してい るが, 油剤に比べて摩耗の増加割合は大きく，切削满 長さが長くなるにつれて油剂との摩耗幅の羑が大きく なっている.ドライ切削の場合, 初期摩耗も小さく, 摩耗は溝 $50 \mathrm{~m}$ まで漸増している。

図 7 に, 外周切れ刃扔よび側面切れ刃の逃げ面摩耗 の比較を示す。油剤 $\mathrm{A}$ および油剤 B の場合，チッピ ングあるいはコーティング膜のはく離から発生したと 思われる局部的に小さな欠けが確認できる。また，外 周切れ刃の逃げ面摩耗では，切れ刃に直角な溝状の摩 耗が見られる。これは超硬合金工具に見られるへアク ラックに似て敀り，超硬合金成分を含むコーティング 材質では，前で述べたように，熱応力により発生した 摩耗形態も考えられる。水道水の場合, 油剂を使用し た場合に見られた局部的な小さい欠けは確認されず, 摩耗形態としては, 潤滑成分の不足による凝着摩耗が 支配的であると思われる。また，切れ扨において溶着 物を確認しており，加工硬化した溶着物の脱落片が工 具を削り取る，いわわアブレージョンも考えられ， 複合的な摩耗形態であると推測される.ドライ切削の 場合，切れ刐に平行に浪湾均一な摩耗が発生しており， チッピングなども起こっておらず，摩耗形態はアブレ シブ摩耗と思われる.

$3 \cdot 2$ クレータ摩耗 工具すくい面は切りくずと 直接接触して高温高圧になり，逃げ面と比べて接触面 積も広いため，逃げ面と比べて切削油剤の潤滑効果な どの性能差が顕著に現れるものと思われ，またタレー 夕摩耗は工具寿命に及济寸重要な因子であると考えら

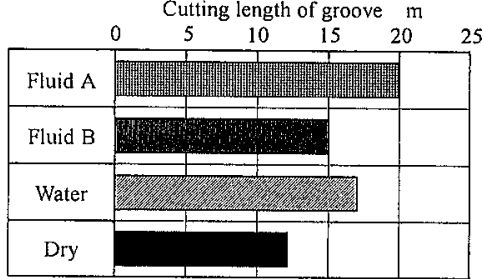

Fig. 8 Comparison of the cutting length of groove when the crater wear occurred

れる。

図 8 は,クレータ摩耗が発生した時点での切削溝長 さの比較である。ここで,クレータ摩耗が発生した時 点とは，コーティング膜がはく離して母材が露出した ときと定義する。油剤 $\mathrm{A}$ と油剤 $\mathrm{B}$ を比較した場合,

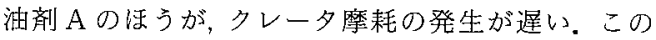
理由として,ソリューブル形の水溶性切削油剤を用い てすくい面にコーティング膜がない場合(4)でも考察 したように，油剤 Aにはポリアルキレングリコール 系の合成潤滑添加㓲を多く含んで扔り，( $\mathrm{Al}, \mathrm{Ti}) \mathrm{N} コ$ ーティング膜の存在下においても，ポリアルキレング リコールの潤滑効果が現れたものと思われる.また， 䍔点以上の温度条件下で析出したポリアルキレングリ コールの粘度効果(7)によることも考光られる、さら

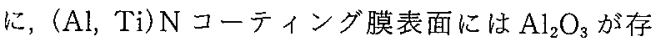
在し, エステルの加水分解によって生じな脂肪酸の力 ルボキシル基が $\mathrm{Al}_{2} \mathrm{O}_{3}$ と反応して，アルミ石けんのよ うな吸着膜を形成しているものと思われる。

一方, 油剂 $\mathrm{A}$ の合成潤滑添加剂の一部を鉱油で置 㨨えた油剤 Bでは，クレータ摩耗の発生が早くなって いる。鉱油のホブ摩耗に及ぼす影響について, 以前, 


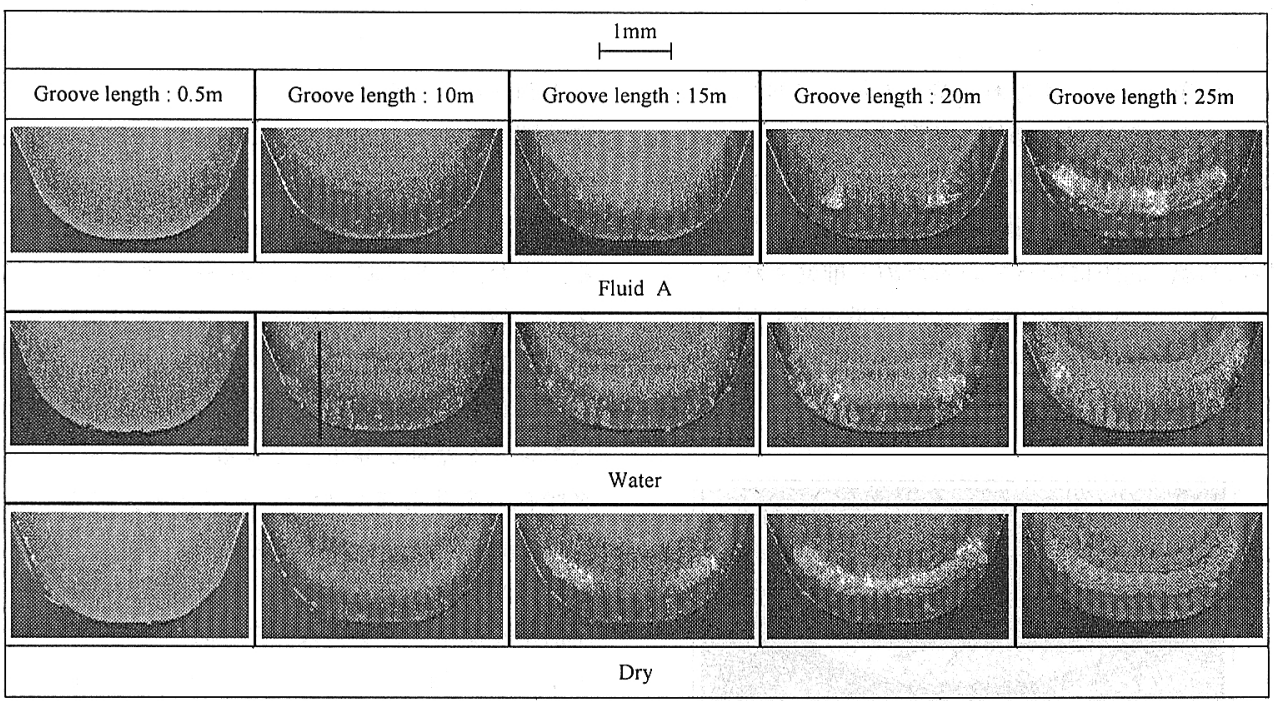

Fig. 9 Changes of the conditions of the rake face with passage of time

著者の一人がコーティングを施していない工具を用い た場合であるが, 水溶性切削油剤中の鉱油が摩耗を大 きくすることを報告している(8).これは, 鉱油の熱伝 導率は水よりもかなり低いため(9), 冷却性能が損なわ れたためであろう。今回はそれに加え，切削加工の㵎 滑状態は境界潤滑が主体であり，エーテル系の合成潤 滑添加剤が減少したことによる境界潤滑性能の不足が 考えられる。

図 3 に示す逃げ面摩耗についても，鉱油を含む油剤 B はわずかに摩耗を大きくしており，クレータ摩耗に おいては，その影響が顕著に現れている．水道水の場 合, 油剤 $\mathrm{A}$ に比べてクレータ摩耗の発生は早いが, 油 剤 B よりも遅い。水道水を用いた場合，すくい面に溶 着物が付着しており，これがクレータ摩耗の発生を抑 制しているものと思われる。ドライ切削の場合，逃げ 面摩耗は小さいが, クレータ摩粍の発生時期は最も早 い。以上より, 油剤 A を使用した場合に,クレータ摩 耗の発生がいちばん遅いことがわかった。

図 9 は,クレータ摩耗の発生が達かった油剂 $\mathrm{A}$ お よび水道水, ドライ切削において, 切削溝 $25 \mathrm{~m}$ まで のすくい面状態の経時変化を示す，切削始めの溝長さ $0.5 \mathrm{~m}$ において, 切りくずとの接触面(以後, 接触面と 略す。後にクレー夕摩耗となる)では，かすかに変色 している程度で, 油剤 $\mathrm{A}$, 水道水およびドライ切削で のすくい面状態の違いは見られない. 溝長さ $10 \mathrm{~m}$ 切 削後では，接触面の跡がさらに鮮明になっているが, 水道水の場合，ノ一ズ丸み部において，局部的なコ一 ティング膜のはく離が見られる。図 10 は, その写真

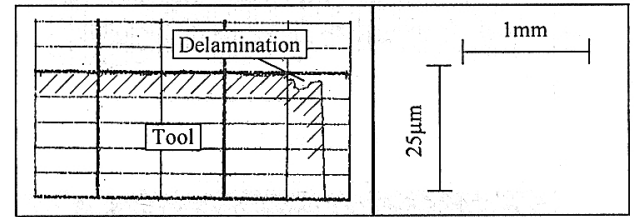

Fig. 10 Delamination of the coating film (water, cutting length of groove of $10 \mathrm{~m}$ )

の縦線の位置を, 粗さ測定器で測定したクレータ摩耗

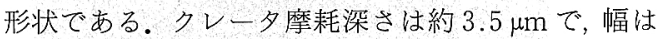
約 $3 \mathrm{~mm}$ である.この形状からコーティング膜はは く離しているが，コーティング膜厚は約 $5 \mu \mathrm{m}$ である ことから母材はまだ現れていないことがわかる。

溝 $15 \mathrm{~m}$ 切削後では, 油剤 $\mathrm{A}$ おうよび水道水の場合は, 接触面の状態は满 $10 \mathrm{~m}$ 切削後とほとんど同じである が，ドライ切削の場合，左右のノーズ丸み部と側面切 れ刃との境界付近にクレータ摩耗がすでに発生してい

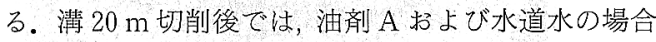
にも，接触面の左右の位置にクレータ摩耗が発生して 抢り，ドライ切削の場合は, 左右のクレータ摩耗はつ ながり, 広い領域のクレータ摩耗に成長している。满 $25 \mathrm{~m}$ 切削後では, 油剤 $\mathrm{A} の$ 場合も, 広い領域のクレ 一夕摩耗に成長している. 水道水の場合, 左右のクレ 一夕摩耗の領域は広くなっているが, まだそれらはつ ながっていない. ドライ切削の場合, 溝 $20 \mathrm{~m}$ 切削後 のクレータ摩耗領域とほぼ同じであるが, クレータが 深くなっている.

一方，ノーズ丸み部と側面切れ刃との境界付近で発 
生したクレータ摩耗は, 複雑なクレータの輪郭から, コーティング膜のはく離から発生したものと推定され る.この位置でクレータ摩耗が発生し始める理由とし て,ホブの切れ注はつの切れ稜を持っており，こ れら切规稜から出た切りくず惿いに流出方向が異 なるため, 切りくずの干涉(10)が起こりここの部分 では特に高温，高压になっているためと推察される。

以上よりすをくい面にコーティング膜がある場合の クレータ摩耗の発生は, 切りくずの繰返し荷重による

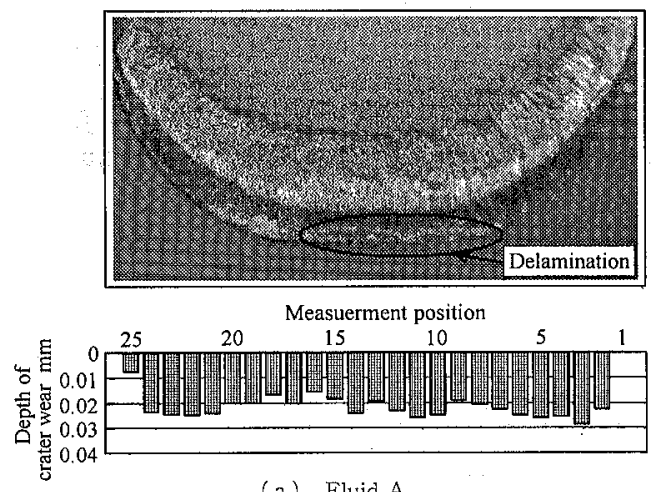

(a) Fluid A

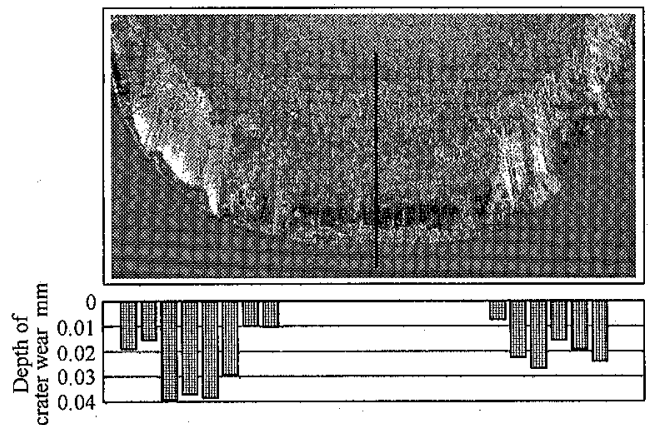

(b) Water
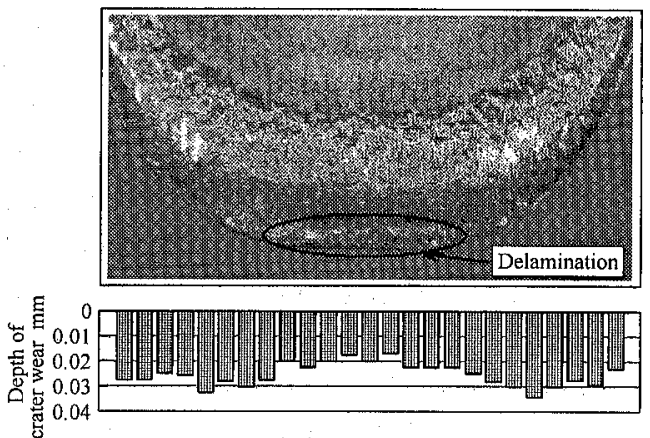

(c) Dry

Fig. 11 Conditionds of the rake face and the depth of the crater wear at each position (cutting length of groove of $50 \mathrm{~m}$ )
熱波労のため，コーティング膜のはく離が起こり，ク レータ摩耗に至っているものと推察される.

清 $50 \mathrm{~m}$ 切削後のすくい面の状態および 25 点の測 定位置でのクレー夕摩耗梁さを図 11 に示す. 油剤 $\mathrm{A}$ の場合, 接触面のほ浪全域にクレー夕摩耗が発生して いるが, 切れ刃に沿ってコーティング膜が残ってい る。また，刃先に频いて，切れ刃にほぼ平行にコーテ イング膜のはく離が見られる。クレータは接触面の中 央および左右の位置で深いところもあるが，ほぼ均一 に摩耗している. 水道水の場合, 接触面の左右の位置 でクレータ摩耗が発生しているが, 中央部ではクレー 夕摩耗は発生していないようである。図 12 に, その 写真の縦線の位置を, 粗さ测定器で測定したすくい面 の状態を示す. 高さ約 $5 \mu \mathrm{m}$ の溶着物が付着しており, 水道水を使用した場合は，溶着物によりクレー夕摩耗 の発生を抑制しているものと思方れる. 本実験では, この溶着物の成分分析は行っていないが, 広井ら ${ }^{(12)}$ は, 構成刐先によって刃先が保護されて工具寿命が長 くなる場合があるとしており，本実験でもこの構成刃 先の効果が考えられる。また, $\mathrm{MnO}_{2}$ などの微細な酸 化物は，切削中の工具表面で搪散による摩耗を阻止す る保護層(ベラーク)学形成し，それは特定の切削速度 筙困(切削温度範囲)で現れる(13)といわれており，本 实験条件下においても，この上うな保護層が形成され ているとも考えられる.

ドライ切削の場合，接触面のほぼ全域にクレータ摩 耗が発生しているが, 油剤 A の場合に比べて切れ为 に沿ってコーティング膜が残っている領域が広い.す なわち, 油剤 $\mathrm{A}$ に比べて, クレー夕摩耗は刃先から離 れた位置に発生している。また，刃先において，油剤 Aで見られた切れ妇に活潘平行にコーティング膜の はく離が確認できる.クレータは接触面の左石の位置 で深く,さらに, クレー夕摩耗面には凹凹があり, 溶 着物が付着しているように見える。

油刻 $\mathrm{A}$ 扔よびドライ切削の場合, 刃先において，切 れ刃にほぼ平行にコーティング膜のはく離が胃られ る.この理由として, 刐先付近 (中央部)のすくい面上

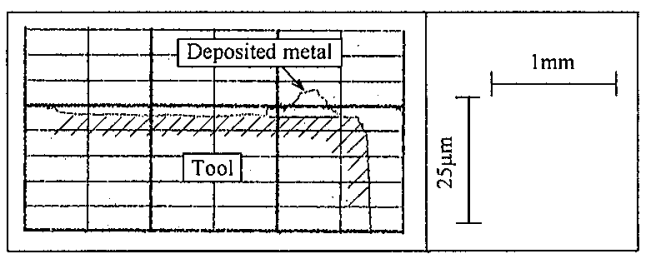

Fig. 12 Deposited metal on the rake face (water, cutting length of groove of $50 \mathrm{~m}$ ) 
では，他の切れ刃位置に比べて厚い切りくずを排出す るため,コーティング膜は切りくずとのより大きな摩 擦抵抗を受け，切りくずの流れる方向，すなわち，刃 先に直角に摩擦応力 (接線応力) を受けるものと思われ る.そのため, 切れ刃にほぼ平行にコーティング膜の はく離が起こるものと推察される。水道水の場合, す くい面に溶着物が付着したため, 切れ刃にほぼ平行な コーティング膜のはく離は確認できなかった。

図 13 は, 溝 $50 \mathrm{~m}$ 切削後のクレー夕摩耗深さの比較 である、クレータ摩耗の最大深さ(测定位置 25 点の中 の最大) 拈よび平均值 (測定位置 25 点の平均)を示す。 油剤 $\mathrm{A}$ と油剤 $\mathrm{B}$ を比較した場合, 油剤 $\mathrm{A}$ のほうがク レータ摩耗は小さい.この理由についても，上で述べ たように, 油剤 $\mathrm{A}$ に含まれるポリアルキレングリコ 一ル系の合成潤滑添加剤の潤滑効果によるものと思わ

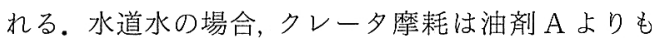
大きいが，油剤 B に比べて小さい. 水道水を用いた場 合は, クレータ摩耗には潤滑性能よりも, 溶着物の影 響が大きいと思われる。ドライ切削の場合, クレータ 摩耗は油剤 $\mathrm{B}$ および水道水よりも小さいが, 油剤 $\mathrm{A}$ よりも大きい，逃げ面摩耗においてドライ切削は有効 であったが, 逃げ面に比べて高温, 高圧になるすくい

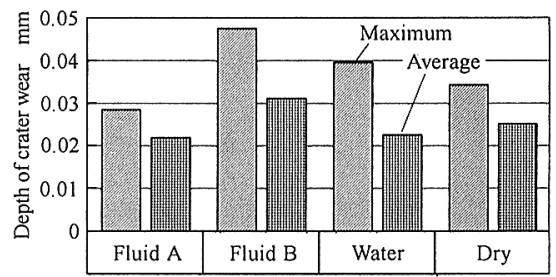

Fig. 13 Comparison of the depth of crater wear (cutting length of groove of $50 \mathrm{~m}$ )

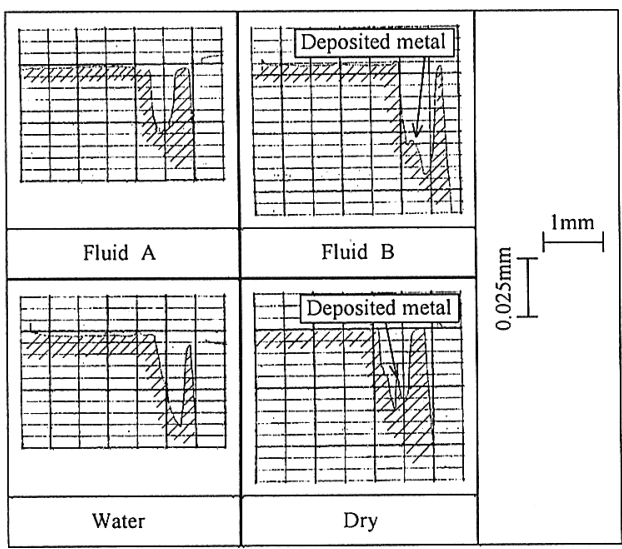

Fig. 14 Profiles of the maximum crater wear (cutting length of groove of $50 \mathrm{~m}$ )
面では，潤滑性能の優れた油郕が有効である。

図 14 K, 满 $50 \mathrm{~m}$ 切削後の最大クレータ摩耗形状を 示す. 油剤 $\mathrm{A}$ の場合, クレー夕摩耗は对先から少し 離れた位置(図 11 参照)に発生しており, 滑らかな形 状を示している。油剤 B の場合, クレータの底に溶着 物の付着と思われる段が付いている。水道水の場合, 溶着物の付着は見られないが, 他のクレータ摩耗の測 定位置では，溶着物の付着が見られる。ドライ切削の 場合も, クレータ摩耗は刃先から少し離れた位置に発 生しており，クレータの底に溶着物の付着したような 突起物が見られる。

$3 \cdot 3$ 仕上げ面粗さ 図 15 に, 仕上げ面粗さ $R_{y}$ の経過曲線を示す. 油剤 $\mathrm{A}$ の場合, 切削溝 $5 \mathrm{~m}$ まで は仕上げ面粗さ $R_{y}$ は $2.0 \mu \mathrm{m}$ 程度であるが, それ以 後は切削終了まで理論粗さ值 $R_{y}=1.4 \mu \mathrm{m}$ とほぼ同じ 值を示し, 粗さは良好である. 油剤 $\mathrm{B}$ の場合, 切削溝 $10 \mathrm{~m}$ までは仕上げ面粗さ $R_{y}$ は 2.5〜3.0 $\mu \mathrm{m}$ を示し, 切削瑇 $30 \mathrm{~m}$ までは減少する傾向があるが，その後は 増加し, 切削終了の溝長さ $50 \mathrm{~m}$ 切削後では $R_{y}$ は 4.3 $\mu \mathrm{m}$ の值を示した. 水道水の場合, 切削溝 $15 \mathrm{~m}$ まで

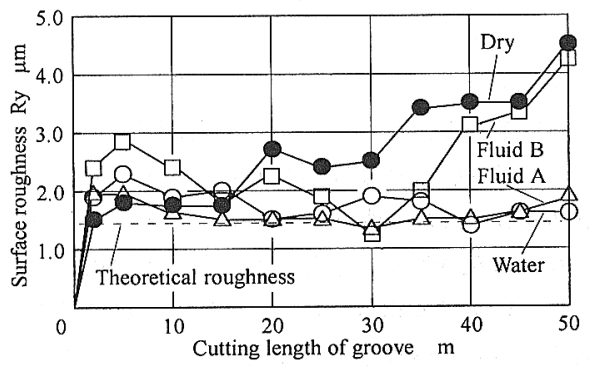

Fig. 15 Progress curves of the surface roughness

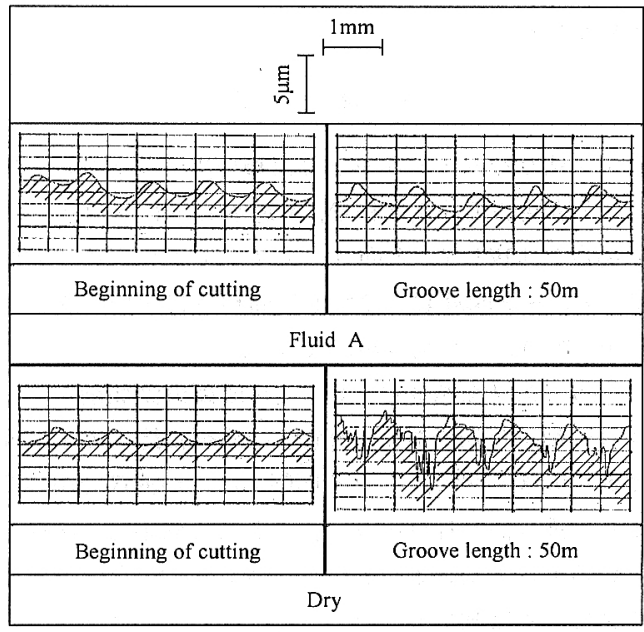

Fig. 16 Profiles of the finished surface 
は仕上げ面粗さ $R_{y}$ は $2.0 \mu \mathrm{m}$ 程度であるが, それ以 後は切削終了まで理論粗さ值とほほ同じ值を示し，良 好である。仕上げ面粗さには，溶着物の影響が大きい と考えられ, 水道水の場合, 工具すくい面に溶着物の 付着が確認され，仕上げ面粗さは大きくなるものと思 われたが,これに反して, 粗さは小さくなった。この 理由として，図 12 に示すすくい面の溶着物の付着状 態より，切れ刃より離れた場所に溶着物が付着してお り, 粗さに影響する刃先には溶着物が付着していない ためであると推察される.ドライ切削の場合, 切削初 期の切削溝 $2 \mathrm{~m}$ では, 仕上げ面粗さ $R_{y}$ は理論粗さと 同じ値を示すが, その後切削終了まで増加する傾向が あり, 溝 $50 \mathrm{~m}$ 切削後では $R_{y}=4.5 \mu \mathrm{m}$ となり, いち ばん大きな值を示した，以上の結果より，仕上げ面粗 さは，合成潤滑添加剤だけを含む油剂 $\mathrm{A}$ を使用した 場合に良好であることがわかった。

図 16 は，油剤 A およびドライ切削の場合の仕上げ 面の粗さ形状を示す. 切削始めと溝 $50 \mathrm{~m}$ 切削後の粗 さ形状である. 油剤 A の場合, 切削始めにおいて, 粗 さの高低が見られるが，ほぼ送り量 $(0.99 \mathrm{~mm} / \mathrm{rev})$ と 同じ間隔で，回転マークがはっきり確認できる，溝 50 $\mathrm{m}$ 切削後においても, 粗さは少し大きくなった程度で あるが, 回転マークも確認でき, 肉眼で見ても仕上げ 面は良好である。ドライ切削の場合，切削始めにおい て, 理論粗さ形状とほほ同じ形状を示しているが, 溝 $50 \mathrm{~m}$ 切削後では，回転マークは確認されるものの，の こぎり状の粗さ形状を示しており, 大きな粗さとなっ ている，仕上げ面粗さには，主として工具摩耗および 溶着物の付着が関係していると思われるが, 本実験で のドライ切削の場合, 図 3 に示す逃げ面摩耗は小さい ことから, 粗さには溶着物の付着が影響しているもの と思われる。

\section{4. 結言}

ホブ切りをシミュレートした舞いツール切削におい て, 水溶性切削油剤 2 種を, 水道水およびドライ切削 の場合と比較して, 全面コーティング工具の逃げ面摩 耗,クレータ摩耗および仕上げ面粗さについて調べた 結果, 次のことが明らかになった。

（1）逃げ面摩耗について，合成潤滑添加剤だけを 含む油剤が有効であり, 水道水は油剤に比べて逃げ面 摩耗を大きくする．ドライ切削のほうが油剤を用いる よりも逃げ面摩耗は小さい.これには熱応力が関係し ているものと思われ，ドライ切削の場合，空転時には 空気による冷却であり, 油剤に比べて空気は熱伝導率 は小さいため, 熱応力も小さくなり, 摩耗が減少する
ことが示唆された。

（2）クレータ摩耗について，ドライ切削に比べて 合成潤滑添加剤だけを含む油剤を使用した場合に、ク レー夕摩耗の発生が遅く、またクレー夕摩耗も小さ い. 逃げ面に比べて高温, 高圧になるすくい面では， 潤滑性能が支配的であることが示唆された。

（３）クレー夕摩耗の発生は，まず，コーティング 膜は熱疲労によりはく離が起こり，母材が現れた後。 切りくずが擦るために、クレータ摩耗は深くなる。ま た，水道水を使用した場合，クレータ摩耗には溶着物 が影響していることが示唆された。

（4）仕上げ面粗さについて，ドライ切削に比べて 油剤を用いたほうが有効であり，合成潤滑添加剂だけ を含む油剤を使用した場合に，仕上げ面粗さはいちば ん小さい.

（5）逃げ面摩耗は，ドライ切削のほうが有利であ るが，クレータ摩耗および仕:トげ面粗さを総合的に見 た場合に，合成潤滑添加剂だけを含む油剂はドライ切 削よりも有効である.

今後, 水溶性切削油剂を使用した場合の工具摩耗の 発生機構を解明するために，油剤とコーティング工具 との反応性抢よび油剤の腐食性について検討すること が課題である。

終わりに, 本研究に対し切削工具を提供していただい た三菱マテリアル神戸ツールズ(株)に謝意を表する。

\section{文献}

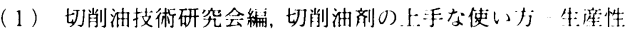
と環境のバランスを若える，切㴥油技術研究会総令資 料, (2001), 1125.

（2）切削油技術研究会編，ドライ、ミスト。ウェット加1：0実 態を探るドライ心ははどこまで叮能か，切㴥油技術 研究会総全瓷料。(200(1)，2 12

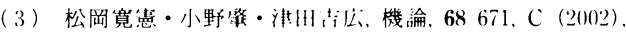
21882195.

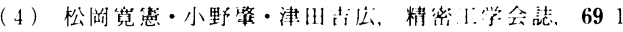
(2003), 110 114.

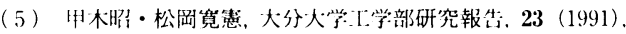
713

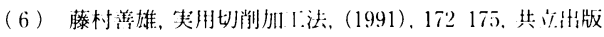

( 7 ) Brown. W. L., Lubricut. Eng., 443 (1988), 168175.

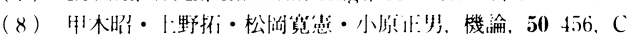
(1984), 15301539

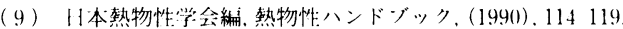

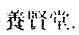

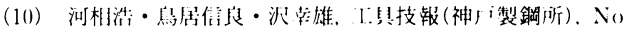
22 (1974), 1426

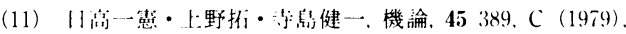
126136.

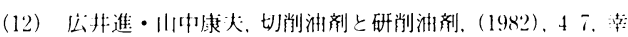
烡原。

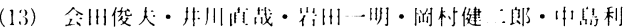

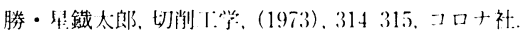

